\title{
"Like a virgin". Correlates of virginity among Italian university students
}

\author{
Manuela Stranges ${ }^{1 *}$ (D) and Daniele Vignoli ${ }^{2}$
}

\author{
* Correspondence: manuela. \\ stranges@unical.it \\ ${ }^{1}$ Department of Economics, \\ Statistics and Finance "Giovanni \\ Anania", University of Calabria, \\ Arcavacata di Rende (CS), Italy \\ Full list of author information is \\ available at the end of the article
}

\begin{abstract}
Virginity, as a status, carries with it enormous personal and social meaning and represents a sexual milestone with high cultural significance. In this paper, we describe the correlates of virginity in Italy by consulting a large-scale survey of university students conducted in 2000 and 2017 ( $N=12,400)$. First, we note a reduction between 2000 and 2017 of both male and female students reporting themselves as virgins at the time of the interview. Second, we highlight the salience of several demographic-, family-, interpersonal-, bodily-, and health-related factors associated with their virginity status. Third, the findings of the present study draw special attention to two crucial characteristics of Italian society: regional divisions and the role of religiosity. We show that, although religiosity is still important to the sexual lives of Italian youths, its relevance is weakening over time. In all, our study extends research on sexuality among Italian youths and sheds light on factors related to their virginity, seeking to feed future research on the topic.
\end{abstract}

Keywords: Virginity status, Italy, Religiosity

\section{Introduction}

Modernization, secularization, more relaxed social norms, and greater gender equality have galvanized important changes in the sexual and affective behaviors of contemporary societies. Such changes are especially relevant when they affect the first stages of the process of building one's own social and relational identity (Rosina, 2004). Although rarely discussed or analyzed, the onset of the transition to adulthood starts with the first sexual experiences during adolescence-particularly in relation to increasing independence, responsibility, and the management of at-risk behaviors (Poscia, La Milia, Lohmeyer, et al., 2015). In this context, the virginity status symbolizes an important touchstone of adolescent development in both contemporary and historical societies (Landor \& Simons, 2019). First, vaginal intercourse embodies enormous personal and social meaning, representing a life-changing event in the transition to sexual adulthood (Carpenter, 2005; Higgins, Trussell, Moore, \& Davidson, 2010). It marks a pivotal rite of passage, one in which young people learn to engage in romantic and/or sexual relationships (O'Sullivan, Cheng, Harris, \& Brooks-Gunn, 2007; Humphreys, 2013). Early sexual events-among which the experience of first coitus represents a highly significant cultural and sexual milestone (Higgins et al., 2010)—loom large in the memories and lives of teenagers (Brown, 1999; Giordano, Longmore, \& Manning,

(c) The Author(s). 2020 Open Access This article is licensed under a Creative Commons Attribution 4.0 International License, which permits use, sharing, adaptation, distribution and reproduction in any medium or format, as long as you give appropriate credit to the original author(s) and the source, provide a link to the Creative Commons licence, and indicate if changes were made. The images or other third party material in this article are included in the article's Creative Commons licence, unless indicated otherwise in a credit line to the material. If material is not included in the article's Creative Commons licence and your intended use is not permitted by statutory regulation or exceeds the permitted use, you will need to obtain permission directly from the copyright holder. To view a copy of this licence, visit http://creativecommons.org/licenses/by/4.0/. 
2006) and can have profound direct and indirect influences on later union formation processes (Manning, Giordano, \& Longmore, 2006, 2008). For example, the normative consideration of vaginal intercourse as "on-time" or "off-time" is important (James-Hawkins, 2019) and may vary depending on such factors as personal characteristics, community, family, or broader social networks (Elder et al. 2003; James-Hawkins, 2019). This paper aims to depict the socio-demographic profiles of virginity among a specific segment of youths in Italynamely, university students.

The first years of tertiary education are a crucial stepping stone for young Italians. University students experience many opportunities for social interacting, forming relationships, and having sex with their peers (Di Mauro, 2008). For many, the university is their first time away from home, and they may well engage in casual sex, unprotected sex, or risky behaviors for the first time (Rosina \& Rivellini, 2004; La Mendola \& Tinto, 2004; Bernardi \& Mencarini, 2004). Past research on the sexuality of Italian university students has mainly focused on issues related to first sexual experience or being sexually active (Billari \& Borgoni, 2002; Dalla-Zuanna \& Crisafulli, 2004; Ongaro, 2004; Castiglioni, 2004; Billari \& Ongaro, 2004; Dalla-Zuanna \& Mancin, 2004; Caltabiano, Castiglioni, \& Dalla-Zuanna, 2004; Billari, Caltabiano, \& Dalla-Zuanna, 2007; Gabrielli \& Borgoni, 2007; Barbagli, Dalla-Zuanna, \& Garelli, 2010; Panatto, Amicizia, Trucchi, et al., 2012; Poscia et al., 2015). The characteristics used to predict virginity among Italian young adults may be consistent with factors contributing to their sexual activity; however, they are not inevitably the converse of each other and may vary (Landor \& Simons, 2019). Insufficient attention has been paid so far to the factors associated with virginity status among Italian young adults. This paper seeks to fill this gap by asking three questions: (i) What are the socio-demographic profiles of Italians with virgin status in their young adulthood? (ii) Have these profiles changed over the last two decades? (iii) Is religiosity still important in the sexual decisions of young Italians and, more importantly, has its role changed over time? Addressing these questions will deepen our understanding of sexual patterns among Italian young adults.

In line with the majority of the literature on sexuality, we define virginity by referring to individuals who have never engaged in vaginal-penile intercourse (e.g., Humphreys, 2013; Landor \& Simons, 2019). The empirical analysis is based on data from the SELFY (Sexual and Emotional Life of Youths) survey, which provides information on the sexual and emotional behaviors of approximately 8000 Italian university students in 2017 and roughly 5000 in 2000-2001 (hereafter, 2000) across all the regions of Italy (DallaZuanna, Caltabiano, Minello, \& Vignoli, 2019). The full comparability between the two surveys enables the pinpointing of changes over time in the prevalence and correlates of virginity. Analytically, this paper follows a descriptive approach. To the best of our knowledge, no up-to-date study on the correlates of virginity exists for Italy. A descriptive study is thus a necessary first step for further analyses.

\section{Background}

\section{Correlates of virginity: literature review}

Most of the research on sexual intercourse has focused on the timing of sexual debut and its subsequent outcomes. Nonetheless, "persons who defy the odds and delay sexual debut beyond adolescence represent an interesting minority group" (Halpern, Waller, Spriggs, \& 
Hallfors, 2006: 926.e2). The qualitative work of Laura Carpenter (2001, 2002, 2005) pioneered research on virginity by delineating the cultural scripts that embody the North American perception of virginity. She found that individuals tended to draw on three fundamental scripts when describing their beliefs surrounding virginity: gift, stigma, and process. Individuals who identified with the gift script typically discussed virginity as a prized possession-something to be highly valued. Individuals who endorsed the stigma script viewed virgin status as something negative and embarrassing to be discarded as swiftly as possible. Individuals who identified with the process script viewed the loss of virginity as part of a process by which people make a transition from adolescence to adulthood. For them, its loss represents a means of gaining experience and becoming more knowledgeable about sexuality.

The cultural significance of virginity is considerable. The transition into adulthood, a loss of sexual innocence and, in some cases, an association with family life courses are all encompassed by it (Humphreys, 2013). This section briefly reviews the scant empirical evidence on the correlates of virginity by delineating the potential relevance of demographic-, family-, interpersonal-, bodily-, and health-related factors. We also cite a number of studies relating to developing countries while bearing in mind that their results are not directly transferable to an Italian context. The review offers input for selecting potential correlates of virginity for our empirical analysis. The majority of these studies use adolescents or students as samples.

Among the demographic correlates of virginity-aside from the well-established negative association with age(see Glei, 1999; Brewster, Cooksey, Guilkey, \& Rindfuss, 1998; Moore, Miller, Glei, \& Morrison, 1995) - the role of gender has received a large emphasis (Trapnell, Meston, \& Gorzalka, 1994; Schechterman \& Hutchinson, 1991). Men and women have traditionally followed different guidelines for sexual behavior (Giordano et al., 2006; Peplau, 2003; Collins, 2000; Sprecher \& Regan, 1996; Crawford \& Popp, 2003). When discussing the gendered nature of virginity, Holland, Ramazanoglu, Sharpe, and Thomson (2000) highlighted that first intercourse represents an empowering, and identity settling, moment for young men, whereas the experience is often faced more cautiously or ambivalently by young women ${ }^{1}$. Following these notions, and in line with prior reflections and empirical research (Carpenter, 2010; Caltabiano, Dalla-Zuanna, \& Rosina, 2006; Meier, 2003; Rostosky, Regnerus, \& Wright, 2003), we opted for segmenting our empirical analysis by gender.

The family context should also be considered. Family structure (e.g., being in a twoparent household), as well as closer child-parent affective relationship, have been put forward as increasing the likelihood of sexual abstinence among adolescents (Miller, Benson, \& Galbraith, 2001). More recently, relevant associations of familial-level factors (family structure and parental quality) and virginity were found among African American young adults (Landor \& Simons, 2019). Moreover, the influence of the family still significantly exerts itself on sexuality even into young adulthood (Mohtasham et al., 2009). More specifically, parental communication is a known protective factor with respect to early-and possibly unprotected-sexual intercourse (Karofsky, Zeng, \& Kosorok, 2000; Miller, Kotchick, Dorse, \& Forehand, 1998; Vazsonyi \& Jenkins, 2010;

${ }^{1}$ For a review of the studies on gender differences in different aspects of sexuality, see Peterson \& Hyde $(2011,2010)$. 
Guetto, Vignoli, \& Lachi, 2020). Consequently, while some adolescents experience parental norms demanding abstinence from sexual activity, others receive mixed messages in which sexual activity is simultaneously condemned, while promoting vis-à-vis the use of contraceptives (Mollborn, 2009). Apart from the important role of parents, recent studies have shown that laterborns are more likely to engage in sexual activity (Argys, Rees, Averett, \& Witoonchart, 2006), and report earlier initiation into sexual activity (Dixon, 1980; Rodgers, Rowe, \& Harris, 1992). This could be explained by middleborns and lastborns employing different personality strategies as an attempt to garner parental attentionwhich may well affect their sexual strategies (Michalski \& Shackelford, 2002). Additionally, the sexual behaviors and attitudes of older children may shape that of their younger siblings (Argys et al., 2006), in turn leading to earlier sexual debuts.

Regarding interpersonal correlates, research has shown that peers exert considerable influence on adolescents. Moreover, this influence also affects first sexual intercourse, net to other confounding factors (Jaccard, Blanton, \& Dodge, 2005). Additional research suggests that men face greater peer pressure to engage in sexual activity than women (Guggino \& Ponzetti, 1997). Bozon \& Rault (2013, 2012), analyzing data about sexual behavior in France, found that nightclubs and discotheques have grown in popularity as places where people find their first life partner and, among the less educated, where they have their first sexual intercourse (see also Kabiru \& Orpinas, 2009). For Norway, Gravningen, Furberg, Simonsen, and Wilsgaard (2012) found that one-fourth of the participants to their crosssectional study of high school students had met their last sexual partner at a private party, bar, or club (23\% of female and $25 \%$ of male students).

The importance of bodily-related aspects has also been shown. A large body of research has documented that physically attractive males were more likely to have more sexual partners and become sexually active earlier in their lives (Rhodes, Simmons, \& Peters, 2005). Self-confidence is closely bound to physical attractiveness. The body mass index $(\text { hereafter, BMI })^{2}$ has been found to be strongly related with body attractiveness toward the lower end of the "normal" range for women and in the high end of the "normal" range for men (Weeden \& Sabini, 2007, 2005). Other factors, such as acne or skin problems, may cause depression and low self-esteem in youths (Revol, Milliez, \& Gerard, 2015)-indeed, skin problems may negatively affect the sex lives of youths (Parker, Heading, Adams, \& Pond, 2010) $)^{3}$. Additionally, self-rated attractiveness has been found to correlate positively with sexual behaviors and sociosexuality (Weeden \& Sabini, 2007).

Many psychological studies have posited that sexual inactivity among physically healthy adults could be considered an indicator of poor emotional well-being (Schnarch \& Maddock, 2003; Weiner-Davis, 2003; Schreiner-Engel \& Schiavi, 1986). As sexual abstinence is most commonly presumed to be involuntary, sexual inactivity has been customarily correlated with poorer mental health (Dunn, Croft, \& Hackett, 1999; Rosen et al., 2009; Shifren, Monz, Russo, Segreti, \& Johannes, 2008). Nevertheless, certain studies have shown that the relationship may depend on other factors, such as sexual desire. For instance, Rosen et al. (2009) found that women with low sexual desire

${ }^{2}$ For most adults, the ideal BMI ranges between 18.5 and 24.9. A BMI below 18.5 is typically classified as underweight; between 18.5 and 24.9 as healthy weight; between 25 and 29.9 as overweight, and between 30 and 39.9 as obese.

${ }^{3}$ For a review of the literature concerning the relationship between skin problems and sexuality, see Magin, Heading, Adams, \& Pond, 2010. 
tended to not report distress over their lack of interest in sex. Similarly, a recent study by Kim, Tam, and Muennig (2017) suggested that the sexually inactive were no less happy than their active counterparts. This finding has challenged the perception (promulgated by popular media) that the absence of partnered sexual activity commonly results in poorer levels of happiness. The authors state that sexual activity may be replaced (or strongly related) by other integral aspects of well-being, such as autonomy, competency/mastery, self-acceptance, life purpose, and personal growth. Furthermore, the relationship between sexual well-being and general happiness has at times been analyzed using only a selection of sexually active participants (Blanchflower \& Oswald, 2004) - an analytical strategy that clearly hinders the extrapolation of results for nonsexually active individuals. Despite the conflicting messages found in previous literature, we have decided to keep a proxy of mental health and poor emotional well-being in our analysis. This decision was due to our scope being mainly descriptive, aiming to underscore several potential correlates of virginity in Italy.

In addition to demographic-, family-, interpersonal-, bodily-, and health-related correlates of virginity, the role of religiosity merits special examination. Decades of research have documented the influence of religious beliefs and the degree of religiosity on sexual activity among young people (Sheeran, Abrams, Abraham, \& Spears, 1993; Trapnell et al., 1994). In particular, the role of religiosity ${ }^{4}$ in promoting virginity among adolescents and young adults has been extensively demonstrated (see Rew \& Wong, 2006; Bersamin, Walker, Fisher, \& Grube, 2006; Brewster \& Tillman, 2008; Lammers, Ireland, Resnick, \& Blum, 2000; Paul, Fitzjohn, Eberhart-Phillips, Herbison, \& Dickson, 2000; Regnerus, 2007; Rostosky, Regnerus, \& Comer Wright, 2003). Cultural messages which often contribute to cultural and social norms, such as the religious prohibition of sex or contraceptive use, clearly shape young women's sexual strategies (Regnerus, 2007). For instance, a study among Croatian college students found that religiosity was related to decreased odds of the sexual debut among women (Štulhofer, Šoh, Jelaska, Baćak, \& Landripet, 2010). Even more recently, Landor and Simons (2019) found that especially religious males had a greater likelihood of having virgin status.

\section{The role of religiosity in Italy}

Thus far, the literature review has summarized the findings of prior research that may serve as a background to the results for the Italian context. The great majority of research conducted for Italy focuses on the first sexual intercourse of youths (see Caltabiano et al., 2006; Castiglioni, 2004; Billari \& Borgoni, 2002), often trying to investigate the timing and correlates of the sexual debut. However, very little has been said about the correlates of virginity, which represents a distinct phenomenon in itself. In our statistical analysis, we considered all the variables proven to be related to virginity from the literature review outlined so faralthough with the limits posed by the variables available in the SELFY dataset. Given the

\footnotetext{
${ }^{4}$ The terms religion and religiosity are often use interchangeably. Popova (2017), examining the effect of religiosity on economic outcomes, refers to the following two definitions: (i) "Religion is any shared set of beliefs, activities, and institutions premised upon faith in supernatural forces" (Iannaccone, 1998, p. 1466); (ii) The individual religiosity implies a self-identification with a particular religious denomination, having religious beliefs, praying, and attending religious services (Need \& Evans, 2001). Although the two terms are very similar, in the following of the paper, we will refer mainly to the term religiosity, considering that we include in the models two variables (one referring to an opinion and one referring to a behavior).
} 
descriptive nature of this study, we have deliberately abstained from formulating specific research hypotheses.

Regardless, there is a peculiarity of the Italian setting that deserves special attention. As in other Southern European societies, Italians are "shaped by the Church and hence strongly committed to the preservation of traditional familyhood" (Esping-Andersen, 1990: 27). In Italy, the influence of the Catholic Church has remained strongly present in the socialization of young people-an influence more marked than in other European contexts (De Santis, Maltagliati, \& Salvini, 2015). Pre-marital sex, cohabitation, and divorce are forbidden by the Church, whereas a high value is placed on marriage and family life. Moreover, the presence of the Vatican City within its borders makes Italy a unique setting for studying the links between religion and family choices. Italian demographers and sociologists have often linked the strong attachment to Catholic values to Italy's delayed diffusion of new family behaviors, such as cohabitation, marital dissolution, or non-marital childbearing (De Sandre, Ongaro, Rettaroli, \& Salvini, 1997; Barbagli \& Saraceno, 1997; Angeli, Pillati, \& Rettaroli, 1999; Castiglioni, 1999; Barbagli, 2000; Barbagli, Castiglioni, \& Dalla-Zuanna, 2003; De Rose, Racioppi, \& Zanatta, 2008; De Rose \& Vignoli, 2011; Caltabiano et al., 2006; Vignoli \& Salvini, 2014).

In Italy, the "institutional" presence of the Church in the daily lives of citizens is not negligible (see Sansonetti, 2009 for a review). For the country, the relationship between religiosity and sexuality has been closely analyzed (see e.g., Rizzi, 2004; Barbagli et al., 2010; Caltabiano et al., 2006; Dalla-Zuanna, De Rose, \& Racioppi, 2005). Using the 2000 release of the SELFY data, Rizzi concluded that "the more people are religious [...], the greater adherence they express to the values of continence and sexual delay" (Rizzi, 2004: 263). This is especially true for girls. The value of virginity is further reinforced by family religious' education during adolescence (Rizzi, 2004).

However, as can be seen from surveys conducted in the 1970s on the middle classes, Italian attitudes were becoming increasingly flexible when applying Catholic precepts, especially in terms of pre-nuptial sexual behavior and contraception (De Sandre et al., 1997). Indeed, Catholicism is not monolithic, as can be seen by the coexistence of many different attitudes towards hierarchy, volunteering, the Pope, and several ethical issues within the country (Garelli, Guizzardi, \& Pace, 2003; Garelli, 2011; Bonarini, 2013; Salvini \& Vignoli, 2014). In this vein, several studies have emphasized the relatively flexible attitudes of Italians towards sexuality and contraception with respect to Catholic doctrine (Dalla-Zuanna et al., 2005; Caltabiano et al., 2006; Barbagli et al., 2010; Vignoli \& Salvini, 2014). As such, the sexual opinions, attitudes, and behaviors of Italians have changed radically over the last decades, especially in the north (Billari et al., 2007; Billari \& Ongaro, 2004; Caltabiano, 2006; Dalla-Zuanna et al., 2019). Sexuality has become increasingly disconnected from reproduction, with sexual pleasure gaining central relevance in the lives of both couples and single people (Barbagli et al., 2010). While there have been decades of research on sexuality in Italy, the linkages between virginity and religiosity remain largely unexplored-especially in a contemporary Italian context.

\section{Data and methods}

\section{Data and sample}

We examined data from the 2000 and 2017 releases of the SELFY survey. Students in bachelor programs of Economics and Statistics were surveyed using the same national sampling procedure and data collection technique-which is to say a self-administrated 
questionnaire completed in the classroom during lectures (Dalla-Zuanna \& Crisafulli, 2004; Caltabiano et al., 2006; Billari et al., 2007). University students are typically considered good subjects for research on sexuality, due to their diverse nature regarding sexual and affective attitudes, opinions, and behaviors (see Keller, 1959; Pitts \& Rahman, 2001; Weeden \& Sabini, 2007; Hines, 2007; Billari et al., 2007; Stinson, 2010).

After excluding incomplete, or jokingly filled out, questionnaires, the SELFY dataset includes 4762 respondents for 2000 and 7842 for 2017. For both years, the data were poststratified at the macro-region level to obtain representative results at the national level. For our analysis, we have excluded certain observations due to missing values randomly distributed among the variables considered (listed and described in the next paragraph). Our final sample is composed of 12,400 students (5979 males and 6,421 females). As mentioned above, we defined virginity in terms of never having engaged in vaginal-penile intercourse ${ }^{5}$.

\section{Descriptives}

Complete descriptives for males and females are reported in the appendix. Regarding our variable of interest, 3104 students declared never having had sexual intercourse: 1352 males (22.61\% of total male students) and 1752 females (27.29\% of total female students). The students interviewed had an average age of 21.08 (21.13 among males and 21.04 among females). $35.59 \%$ of students were born in a region in the north of Italy (37.2\% for males and $34.11 \%$ for females), $26.14 \%$ in the center (26.54\% for male and $25.76 \%$ for female) and $38.27 \%$ in the south (36.26\% for males and $40.13 \%$ for females).

Figure 1 displays the distribution of virginity by gender and year and shows important changes over time. Considering both genders together, in 2000 one third of the sample had never had sexual intercourse, whereas this number was at less than $20 \%$ in 2017. It can be seen that there were lower incidences of virginity in 2017 than in 2000 for both males and females. In particular, $30.22 \%$ of males were virgins in the 2000 sample, compared to $18.80 \%$ in 2017. Among females, the virgins were at $35.64 \%$ in 2000 and $21.10 \%$ in 2017. The values for females were always found to be higher than those for males.

\section{Method}

The study of the life course in demographic and sociological research has been dominated by the event-based approach, which is used to investigate the causes of an event's timing. Researchers have typically used either single-process hazard models, enabling them to analyze how a certain process is determined by other processes; or multi-process hazard models, which allow them to study the mutual interdependencies between parallel processes. However, focusing on time-to-event would lead us to home in on the transition (or non-transition) to first sexual intercourse, without providing us with the range of characteristics associated with holding virgin status in the first years of tertiary education. Thus, in order to describe the different characteristics of virgin students, we opted for a logit model to contrast virgins against non-virgins. This strategy is similar to sociological and demographic research addressing childlessness, where investigating the correlates of the "nonevent" is more important than investigating the timing of the "event" (e.g., Tanturri \&

\footnotetext{
${ }^{5}$ We opted for this definition of virginity because we wanted to concentrate on those who have not yet had first heterosexual intercourse. We are aware of this notion's limitations as there are many other sexual practices (such as oral sex, mutual masturbation, same sex pleasuring, and other sources of physical pleasure) which are not included.
} 


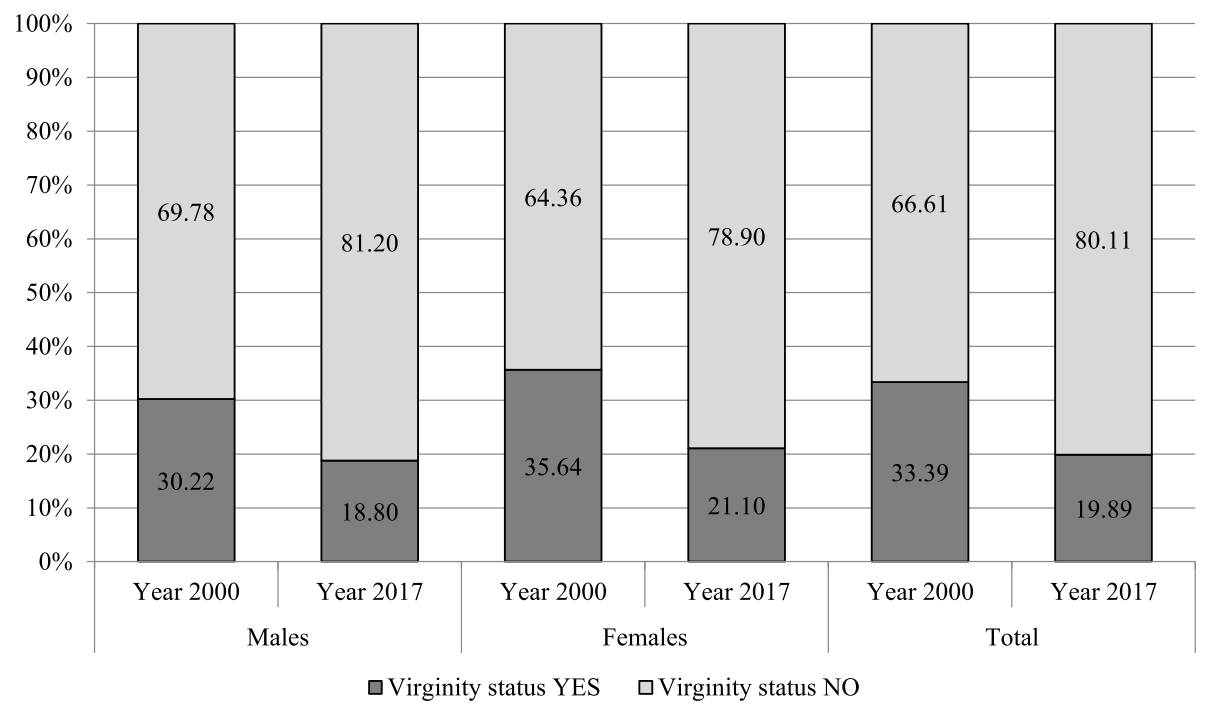

Fig. 1 Distribution of virginity by gender and year

Mencarini, 2008). Specifically, the present study scrutinizes the correlates of virginity among Italian university students through the following logistic specification:

$$
\log \left(\frac{p}{1-p}\right)=\beta_{0}+\beta_{1} X_{1}+\beta_{2} \text { year } 2017
$$

Using this specification, the dependent variable "virginity status" is assessed through asking the respondent whether they had or had not engaged in sexual intercourse. We coded it as a dummy, assuming a value of 1 if the respondent had never had complete sexual intercourse (and 0 otherwise). $X_{i}$ is a vector of covariates (listed in detail below). We included a dummy variable for the year 2017 (vs. 2000).

We included age ${ }^{6}$ and being the firstborn ${ }^{7}$ as demographic correlates. To account for family background, we included mother's and father's education (coded as the number of years corresponding to the highest level of education achieved) $)^{8}$, and a dummy for parents being separated or divorced. From the questions concerning the affective relationship with parents between 14 and 18 years, we built two dummies for "having a balanced or intense relationship" with the mother and father separately (versus having a distant relationship or having none at all). Finally, we have included a dummy "having talked in-depth about sex with parents" (regarding sexual development, diseases, or contraception) ${ }^{9}$.

\footnotetext{
${ }^{6}$ We have not included the square term in the final models because the relationship between virginity and age is clearly linear. Moreover, the age interval is very short (from 18 to 26 years). As a proof, we have run a preliminary model including both terms and the square term was negative and not significant.

${ }^{7}$ We tried another specification to take into account the birth order and number of siblings. We built three dummies: firstborn (of more siblings), laterborn, or only-child. None of these variables proved to have a significant relationship with virginity, so we kept only the birth order variable in the main models. Results are available upon request.

${ }^{8}$ We have tried other specifications (e.g., levels of schooling instead of years of education) and obtained similar results.

${ }^{9}$ We first coded each one of the three original variables into a dummy taking value 1 if they had talked in depth with their parents and then built the variable assuming value 1 if they had talked in depth on "at least" one of the three aspects.
} 
We included in the model equation the BMI as a proxy of attractiveness, along with its square term to account for overweightness. We also accounted for the presence of at least one bodily problem (including halitosis, excessive sweating, and severe acne) between the ages of 14 and 18. Next to these covariates, the model includes current satisfaction levels with the respondents' own body image-a dummy equal to 1 if they declare themselves to be quite or fully satisfied with their own current body image. We additionally inserted a dummy variable for detecting traces of depression, starting with the question: "How much do you agree with the sentence "Sometimes I have the impression to live with no scope" (coded as 1 for those who answered "quite agree" or "fully agree"; and 0 otherwise).

Other additional covariates included "having attended the discotheque often or very often (versus never or sometimes) between the ages of 16 and 18" and being an "off-site" student. This dummy was included as we wanted to test whether living outside the social context where they have grown up could somehow affect students' virginity status. For instance, those moving from the south to the north for a university come from a traditional social context and are likely to experience different, and often less traditional, contexts. Additionally, these students are far from home, out of parental control, and living for the first time in a different place-all factors which could potentially influence their sexual behaviors.

Given the strong relationship between religiosity and sexuality in Italy, we included two variables: the first was a dummy obtained from the question: "How important is religion in life?" coded as 1 if the response was either "quite" or "very important" and 0 otherwise (little important or not important at all); the second was a dummy about current participation in religious groups, assuming a value of 1 if the answer was given as "sometimes," "often" or "very often" (versus rarely or never).

Finally, we included covariates for the area of birth (center, south, with north as a reference) to account for the fact that the south has a more traditional social context (Billari \& Borgoni, 2002; Caltabiano et al., 2006).

We ran separate models for male and female students. All models were estimated with robust standard errors.

\section{Results}

\section{Main models}

Table 1 illustrates the results of the main models run separately for male and female students ${ }^{10}$. We are interested in uncovering the sign and magnitude of each correlate rather than disentangling specific mechanisms or causal pathways.

As expected, age was negatively related to virginity both for males (odds ratio, OR = $0.717, p$ value $<0.001)$ and females $(\mathrm{OR}=0.764, p$ value $<0.001)$ : growing older reduces the probability of maintaining virgin status.

Family characteristics are also meaningful. As the mother's years of education increase, the probability of being a virgin among females and males decreases (however, the estimates are statistically precise only for male students ${ }^{11}$ ). The level of the father's education displays a different pattern, but the estimates are not statistically precise ${ }^{12}$.

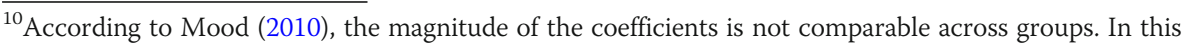
section, we simply present the results for males and females without discussing gender differences, and we report the odds ratios and exact $p$ values for completeness.

${ }^{11}$ For males $\mathrm{OR}=0.963, p$ value $=0.001$. For females $\mathrm{OR}=0.987, p$ value $=0.225$.

${ }^{12}$ For males $\mathrm{OR}=1.006, p$ value $=0.585$. For females $\mathrm{OR}=1.000, p$ value $=1.000$.
} 
Table 1 Correlates of virginity status among Italian students, odds ratios

\begin{tabular}{|c|c|c|}
\hline & Males (1) & Females (2) \\
\hline \multicolumn{3}{|l|}{ Demographics } \\
\hline \multirow[t]{2}{*}{ Age } & $0.717^{* * *}$ & $0.764^{* * *}$ \\
\hline & $(0.020)$ & $(0.018)$ \\
\hline \multirow[t]{2}{*}{ First born } & 1.098 & 1.007 \\
\hline & $(0.075)$ & $(0.062)$ \\
\hline \multicolumn{3}{|l|}{ Family } \\
\hline \multirow[t]{2}{*}{ Father's education (number of years) } & 1.006 & 1.000 \\
\hline & $(0.012)$ & $(0.010)$ \\
\hline \multirow[t]{2}{*}{ Mother's education (number of years) } & $0.963^{* *}$ & 0.987 \\
\hline & $(0.011)$ & $(0.011)$ \\
\hline \multirow[t]{2}{*}{ Parents separated or divorced } & $0.780^{*}$ & $0.686^{* *}$ \\
\hline & $(0.091)$ & $(0.084)$ \\
\hline \multirow[t]{2}{*}{ Balanced or intense relationship with the father } & $0.808^{*}$ & $1.267^{* *}$ \\
\hline & $(0.071)$ & $(0.097)$ \\
\hline \multirow[t]{2}{*}{ Balanced or intense relationship with the mother } & $1.395^{* *}$ & $1.264^{*}$ \\
\hline & $(0.178)$ & $(0.127)$ \\
\hline \multirow[t]{2}{*}{ Have talked in depth with parents about sex } & $0.703^{* * *}$ & $0.713^{* * *}$ \\
\hline & $(0.056)$ & $(0.048)$ \\
\hline \multicolumn{3}{|l|}{ Interpersonal aspects } \\
\hline \multirow[t]{2}{*}{ Having attended the disco often or very often between 16 and 18 years } & $0.303^{* * *}$ & $0.471^{* * *}$ \\
\hline & $(0.022)$ & $(0.032)$ \\
\hline \multirow[t]{2}{*}{ Off-site student } & 0.936 & 1.041 \\
\hline & $(0.076)$ & $(0.082)$ \\
\hline \multicolumn{3}{|l|}{ Bodily and health-related aspects } \\
\hline \multirow[t]{2}{*}{ Satisfaction about own body image nowadays } & $0.617^{* * *}$ & 0.941 \\
\hline & $(0.053)$ & $(0.065)$ \\
\hline \multirow[t]{2}{*}{ BMI } & $0.691^{* *}$ & 1.051 \\
\hline & $(0.078)$ & $(0.087)$ \\
\hline \multirow[t]{2}{*}{$\mathrm{BMI}^{2}$} & $1.007^{* *}$ & 1.001 \\
\hline & $(0.002)$ & $(0.002)$ \\
\hline \multirow[t]{2}{*}{ Having had at least one physical problem between the 14 and 18 years } & $1.232^{* *}$ & $1.228^{* *}$ \\
\hline & $(0.089)$ & $(0.081)$ \\
\hline \multirow[t]{2}{*}{ Depression } & $1.324^{* * *}$ & $1.307^{* * *}$ \\
\hline & $(0.095)$ & $(0.084)$ \\
\hline \multicolumn{3}{|l|}{ Religion } \\
\hline \multirow[t]{2}{*}{ Opinion about the importance of religion in life } & $1.446^{* * *}$ & $1.468^{* * *}$ \\
\hline & $(0.106)$ & $(0.102)$ \\
\hline \multirow[t]{2}{*}{ Participation in religious groups } & $1.819^{* * *}$ & $1.538^{* * *}$ \\
\hline & $(0.176)$ & $(0.116)$ \\
\hline \multicolumn{3}{|l|}{ Time and context } \\
\hline \multirow[t]{2}{*}{ Area of birth: Centre Italy (ref. North Italy) } & 0.961 & 0.870 \\
\hline & $(0.081)$ & $(0.071)$ \\
\hline \multirow[t]{2}{*}{ Area of birth: South Italy } & $0.681^{* * *}$ & 0.980 \\
\hline & $(0.056)$ & $(0.072)$ \\
\hline
\end{tabular}


Table 1 Correlates of virginity status among Italian students, odds ratios (Continued)

\begin{tabular}{lll}
\hline & Males (1) & Females (2) \\
\hline Year 2017 & $0.647^{* * *}$ & $0.447^{* * *}$ \\
$N$ & $(0.055)$ & $(0.034)$ \\
${\text { Pseudo- } R^{2}}$ & 5979 & 6421 \\
\hline
\end{tabular}

Notes: The table reports odds ratios of logit models' estimates based SELFY data (cumulative dataset 2000 and 2017). The dependent variable is "virginity status." Robust standard errors (corrected for heteroskedasticity) are reported in parentheses. The symbols *****, and * indicate that coefficients are statistically significant, respectively, at the 1,5 , and $10 \%$ level, respectively

Parental separation reduces the probability of being a virgin for students of both sexes: the OR is $0.780(p$ value $=0.033)$ for males and $0.686(p$ value $=0.002)$ for females. Interestingly, we found contrasting results about having balanced or intense affective relationship with the father for both sexes: for males, it related negatively with virginity status $(\mathrm{OR}=0.808, p$ value $=0.015)$, while for females, the relation was positive $(\mathrm{OR}=$ 1.267, $p$ value $=0.002$ ). The balanced or intense affective relationship with the mother positively related to virginity status for both genders: for males, the OR was equal to $1.395(p$ value $=0.009)$, while the OR was equal to 1.264 $(p$ value $=0.020)$ for females. Students with an ongoing dialog with their parents about sexuality were found to be less likely to hold virgin status: the OR for males was equal to 0.703 ( $p$-value $<0.001$ ), while for females the OR was equal to 0.713 ( $p$ value $<0.001$ ). Finally, being a firstborn was not shown to offer statistically precise or clear-cut effects ${ }^{13}$.

Regarding interpersonal relations, having attended disco often or very often (as opposed to never or sometimes) between the age of 16 and 18 was significant, and negatively related to the virginity status of both genders (males: $\mathrm{OR}=0.303, p$ value < 0.001; females: $\mathrm{OR}=0.471, p$ value $<0.001$ ). Being an off-site student had a negative relation with virginity for males, and a positive relationship for females (these estimates, however, are not statistically precise).

Bodily-related characteristics, vis-à-vis self-esteem and own body image, proved to be important. Satisfaction with body image was negatively related to virginity, with statistically precise estimates for males ${ }^{14}$. We noted that the relationship between BMI and virginity was nonlinear for males: as BMI grows (from underweight to ideal weight), the likelihood of being a virgin decreases; then, as BMI grows further (from regular weight to overweight), the likelihood of virginity increases. Virginity status is strongly related to having experienced some physical problems between the ages of 14 and 18 (at least one problem of halitosis, excessive sweating, and severe acne): the OR is equal to $1.232(p$ value $=0.004)$ for males and $1.228(p$ value $=0.002)$ for females. The relationship between depression and virginity was found to be positive for both males (OR $=1.324, p$ value $<0.001)$ and females $(\mathrm{OR}=1.307, p$ value $<0.001)$. It is worth remembering that our models pointed out only associations, with limited power to inform us of causal relationships.

Both variables concerning religiosity are statistically precise and strongly related to virginity status. For males, considering religion to be quite or very important in life is

\footnotetext{
${ }^{13}$ For males, $\mathrm{OR}=1.098, p$ value $=0.167$. For females, $\mathrm{OR}=1.007, p$ value $=0.906$.

${ }^{14}$ For males, $\mathrm{OR}=0.617, p$ value $<0.001$. For females, $\mathrm{OR}=0.941, p$ value $=0.372$.
} 
related to an increase in the probability of being a virgin $(\mathrm{OR}=1.446, p$ value $<0.001)$, as well as current participation in religious groups $(\mathrm{OR}=1.819, p$ value $<0.001)$. Also for females, the probability of being a virgin is higher for those who consider religion important $(\mathrm{OR}=1.468, p$ value $<0.001)$ and for those who participate in religious groups $(\mathrm{OR}=1.538, p$ value $<0.001)$.

\section{Time and context}

Time and context are crucial to describing the characteristics of virgin students (see Table 1). Those interviewed in 2017 have a lower probability of virgin status than those interviewed in 2000. We also found the same association for those born in central or southern Italy compared to those born in the north.

To exploit how the regional divide may have changed over time, we ran additional regressions by splitting the sample by year $(2000 \text { vs. } 2017)^{15}$. The results (Table 2) suggest that in 2000, the association between the area of origin and virginity had a different direction. In particular, with respect to males born in the north, those born in the center showed a positive association ( $p$ value $=0.765$ ), whereas being born in the south is still showed to be negatively related with virginity (the estimate is not statistically precise, $p$ value $=0.141$ ). For females, with respect to those born in the north, being born in the center was negatively associated with virginity ( $p$ value $=0.627$ ), while being born in the south showed a positive relation (with a $10 \%$ statistical precision rating).

In models for 2017, all estimated coefficients gained statistical precision except for center in the male sample ( $p$ value $=0.258$ ). For males, being born in the south or center, compared with being born in the north, was negatively related to virginity. However, there emerged a different pattern for females: the coefficients for center and south were both negative in this case (center, $\mathrm{OR}=0.773, p$ value $=0.027$; south, $\mathrm{OR}=0.774$, $p$ value $=0.016)$-results suggestive of a reduction in the length of the social distance in terms of sexuality between the north and south of Italy.

To assess in more depth the changes over time in the correlates of virginity, we ran several additional models introducing interaction terms between each covariate and the year of the survey (2000 vs. 2017). We generally found no meaningful differences between the two time points (results available upon request). On the contrary, for the two variables related to religiosity (importance of religion in life and participation in religious groups), we found a relevant change over time. As such, the role of religiosity is further explored in the next Section.

\section{A focus on the change of the relationship between religiosity and virginity over time}

Descriptively speaking, there has been a strong decline in those who declare religion to be quite or very important (Fig. 2a), and a parallel increase in those declaring it to be

\footnotetext{
${ }^{15}$ As for separate estimates by gender, we discuss results for each model without comparing the magnitude of the effects across them (see, Mood, 2010). To check whether the differences by year in the coefficients obtained in the separated models for 2000 and 2017 for the variables "center" and "south" are statistically significant, we ran a Wald chi-square test (separately by gender). Results show that for center the differences between 2000 and 2017 are not significant, both for males (males: $\operatorname{chi}^{2}[1]=0.88$, Prob $>\operatorname{chi}^{2}=0.348$ ) than for females $\left(\mathrm{chi}^{2}[1]=1.55\right.$, Prob $\left.>\mathrm{chi}^{2}=0.214\right)$. For south, the difference between 2000 and 2017 is significant both in the male sample $\left(\mathrm{chi}^{2}[1]=3.82\right.$, Prob $\left.>\operatorname{chi}^{2}=0.051\right)$ and in the female sample $\left(\mathrm{chi}^{2}[1]=9.09\right.$, Prob $>$ chi $^{2}=0.003$ ).
} 
Table 2 Main models by year, odds ratios

\begin{tabular}{|c|c|c|c|c|}
\hline & \multicolumn{2}{|l|}{2000} & \multicolumn{2}{|l|}{2017} \\
\hline & $\begin{array}{l}\text { Males } \\
\text { (1) }\end{array}$ & $\begin{array}{l}\text { Females } \\
(2)\end{array}$ & $\begin{array}{l}\text { Males } \\
\text { (3) }\end{array}$ & $\begin{array}{l}\text { Females } \\
\text { (4) }\end{array}$ \\
\hline \multicolumn{5}{|l|}{ Demographics } \\
\hline \multirow[t]{2}{*}{ Age } & $0.723^{* * *}$ & $0.779^{* * *}$ & $0.715^{* * *}$ & $0.738^{* * *}$ \\
\hline & $(0.029)$ & $(0.024)$ & $(0.027)$ & $(0.027)$ \\
\hline \multirow[t]{2}{*}{ First born } & 1.052 & 0.935 & $1.163^{*}$ & 1.072 \\
\hline & $(0.117)$ & $(0.082)$ & $(0.101)$ & $(0.093)$ \\
\hline \multicolumn{5}{|l|}{ Family } \\
\hline \multirow[t]{2}{*}{ Father's education (number of years) } & 1.009 & 0.993 & 1.006 & 1.009 \\
\hline & $(0.018)$ & $(0.014)$ & $(0.015)$ & $(0.015)$ \\
\hline \multirow[t]{2}{*}{ Mother's education (number of years) } & $0.952^{* * *}$ & 0.987 & $0.972^{*}$ & 0.993 \\
\hline & $(0.017)$ & $(0.015)$ & $(0.016)$ & $(0.016)$ \\
\hline \multirow[t]{2}{*}{ Parents separated or divorced } & 1.084 & 0.753 & $0.683^{* * *}$ & $0.618^{* * *}$ \\
\hline & $(0.239)$ & $(0.141)$ & $(0.096)$ & $(0.101)$ \\
\hline \multirow[t]{2}{*}{ Balanced or intense relationship with the father } & $0.757^{* *}$ & $1.325^{* * *}$ & 0.852 & 1.191 \\
\hline & $(0.099)$ & $(0.130)$ & $(0.103)$ & $(0.148)$ \\
\hline \multirow[t]{2}{*}{ Balanced or intense relationship with the mother } & $1.439^{* *}$ & 1.212 & 1.314 & 1.317 \\
\hline & $(0.243)$ & $(0.150)$ & $(0.277)$ & $(0.239)$ \\
\hline \multirow[t]{2}{*}{ Have talked in depth with parents about sex } & $0.739^{* *}$ & $0.788^{* *}$ & $0.684^{* * *}$ & $0.657^{* * *}$ \\
\hline & $(0.090)$ & $(0.075)$ & $(0.072)$ & $(0.063)$ \\
\hline \multicolumn{5}{|l|}{ Interpersonal aspects } \\
\hline \multirow{2}{*}{$\begin{array}{l}\text { Having attended the disco often or very often between } 16 \text { and } \\
18 \text { years }\end{array}$} & $0.335^{* * *}$ & $0.548^{* * *}$ & $0.282^{* * *}$ & $0.393^{* * *}$ \\
\hline & $(0.039)$ & $(0.052)$ & $(0.027)$ & $(0.040)$ \\
\hline \multirow[t]{2}{*}{ Off-site student } & 0.975 & 1.086 & 0.926 & 1.020 \\
\hline & $(0.228)$ & $(0.215)$ & $(0.082)$ & $(0.089)$ \\
\hline \multicolumn{5}{|l|}{ Bodily and health-related aspects } \\
\hline \multirow[t]{2}{*}{ Satisfaction about own body image nowadays } & $0.510^{* * *}$ & $0.809^{* *}$ & $0.679 * * *$ & 1.045 \\
\hline & $(0.080)$ & $(0.081)$ & $(0.070)$ & $(0.100)$ \\
\hline \multirow[t]{2}{*}{ BMI } & 0.711 & 0.965 & $0.677^{* * *}$ & 1.112 \\
\hline & $(0.179)$ & $(0.124)$ & $(0.088)$ & $(0.123)$ \\
\hline \multirow[t]{2}{*}{$\mathrm{BMI}^{2}$} & 1.007 & 1.003 & $1.007^{* * *}$ & 1.000 \\
\hline & $(0.006)$ & $(0.003)$ & $(0.003)$ & $(0.002)$ \\
\hline \multirow{2}{*}{$\begin{array}{l}\text { Having had at least one physical problem between the } 14 \text { and } \\
18 \text { years }\end{array}$} & $1.242^{*}$ & 1.169 & $1.223^{* *}$ & $1.317^{* * *}$ \\
\hline & $(0.148)$ & $(0.112)$ & $(0.112)$ & $(0.122)$ \\
\hline \multirow[t]{2}{*}{ Depression } & 1.094 & $1.318^{* * *}$ & $1.490^{* * *}$ & $1.279 * * *$ \\
\hline & $(0.133)$ & $(0.123)$ & $(0.133)$ & $(0.114)$ \\
\hline \multicolumn{5}{|l|}{ Religion } \\
\hline \multirow[t]{2}{*}{ Opinion about the importance of religion in life } & $1.542^{* * *}$ & $1.765^{* * *}$ & $1.417^{* * *}$ & $1.381^{* * *}$ \\
\hline & $(0.184)$ & $(0.193)$ & $(0.133)$ & $(0.128)$ \\
\hline \multirow[t]{2}{*}{ Participation in religious groups } & $2.202^{* * *}$ & $2.129^{* * *}$ & $1.567^{* * *}$ & 1.002 \\
\hline & $(0.326)$ & $(0.218)$ & $(0.206)$ & $(0.121)$ \\
\hline Context & & & & \\
\hline Area of birth: Centre Italy (ref. North Italy) & 1.041 & 0.946 & 0.885 & $0.773^{* *}$ \\
\hline & $(0.142)$ & $(0.108)$ & $(0.096)$ & $(0.090)$ \\
\hline Area of birth: South Italy & 0.824 & $1.204^{*}$ & $0.593^{* * *}$ & $0.774^{* *}$ \\
\hline
\end{tabular}


Table 2 Main models by year, odds ratios (Continued)

\begin{tabular}{|c|c|c|c|c|}
\hline & \multicolumn{2}{|l|}{2000} & \multicolumn{2}{|l|}{2017} \\
\hline & $\begin{array}{l}\text { Males } \\
\text { (1) }\end{array}$ & $\begin{array}{l}\text { Females } \\
\text { (2) }\end{array}$ & $\begin{array}{l}\text { Males } \\
\text { (3) }\end{array}$ & $\begin{array}{l}\text { Females } \\
\text { (4) }\end{array}$ \\
\hline & (0.109) & $(0.121)$ & $(0.062)$ & $(0.082)$ \\
\hline N & 1,950 & 2,744 & 4,029 & 3,677 \\
\hline Pseudo- $R^{2}$ & 0.138 & 0.121 & 0.139 & 0.110 \\
\hline
\end{tabular}

Notes: The table reports odds ratios of logit models' estimates based SELFY data (separate estimations by year). The dependent variable is "virginity status." Robust standard errors (corrected for heteroskedasticity) are reported in parentheses. The symbols ***, **, and * indicate that coefficients are statistically significant, respectively, at the 1,5 , and 10 percent level, respectively

unimportant-irrespective of gender and virginity status. The share of those declaring religion important in life was higher among virgins, both for male and female students in both time points. An analogous pattern may be found for participation in religious groups (Fig. 2b): a general contraction in the level of participation over time and a lower participation for non-virgins. This changing pattern is confirmed also by the chi ${ }^{2}$ value of association between each religiosity variable and virginity status, which was always found to be higher than the usual threshold (at 1 degree of freedom)-i.e., the $\mathrm{H}_{\mathrm{o}}$ null hypothesis that results are due to the case has therefore been rejected.

To gain a deeper insight into the role religiosity plays, we estimated a set of models augmented by interaction terms between the year 2017 and each religiosity dummy. Interaction terms allow disentangling and interpreting the difference in the effect of each variable across time ${ }^{16}$. The results of these augmented models can be seen in Table 3.

The results for "Opinion about the importance of religion in life" (columns 1 and 2) show that in 2000, this variable is significant and positively associated with virginity for both males $(\mathrm{OR}=1.631, p$ value $<0.001)$ and females $(\mathrm{OR}=1.950, p$ value $<0.001)$, while the magnitude of this association has reduced for 2017. Particularly, the relationship was no longer relevant for males in $2017(\mathrm{OR}=1.344=1.631 \times 0.824, z=-1.35$, $p$ value $=0.177)$. For females, however, those who declared in 2017 that religion was quite or very important in life had a statistically and significantly higher probability of being a virgin $(20.1 \%)$ compared to those who declared it to be unimportant $(\mathrm{OR}=$ $1.201=1.950 \times 0.616, z=-3.61, p$ value $<0.001)$.

Regarding "Participation to religious groups," we found the OR for 2000 to be 2.626 ( $p$ value $<0.001)$ for males and $2.192(p$ value $<0.001)$ for females. Hence, the probability of being a virgin was over double for those who participated in religious groups. The interaction terms showed a reduction in the magnitude of the coefficients both for male and female students in 2017: for males, the OR was $1.547(2.262 \times 0.684, z=-$ $2.00, p$ value $=0.046)$, and for females, it was equal to $0.978(2.192 \times 0.446, z=-5.35$,

\footnotetext{
${ }^{16}$ Preliminarly, we have checked whether the differences in the coefficients obtained in the separated models by year for the variable "opinion about religion" are statistically significant, using a Wald chi-square test (separately by gender). Results show that, for males, the difference between 2000 and 2017 is not significant $\left(\operatorname{chi}^{2}[1]=0.31\right.$, Prob $\left.>\operatorname{chi}^{2}=0.577\right)$. For females, the difference between the two years is significant, although at $10 \%$ level $\left(\mathrm{chi}^{2}[1]=2.93\right.$, Prob $\left.>\mathrm{chi}^{2}=0.087\right)$. The same test was conducted for participation in religious groups". Results show that the differences between 2000 and 2017 (for both genders) for the coefficients of this variable are significant, although at different thresholds $\left(\right.$ males $\operatorname{chi}^{2}[1]=2.95$, Prob $>\operatorname{chi}^{2}=0.086$; females $\operatorname{chi}^{2}[1]=22.72$, Prob $>\operatorname{chi}^{2}=0.000$ ).
} 


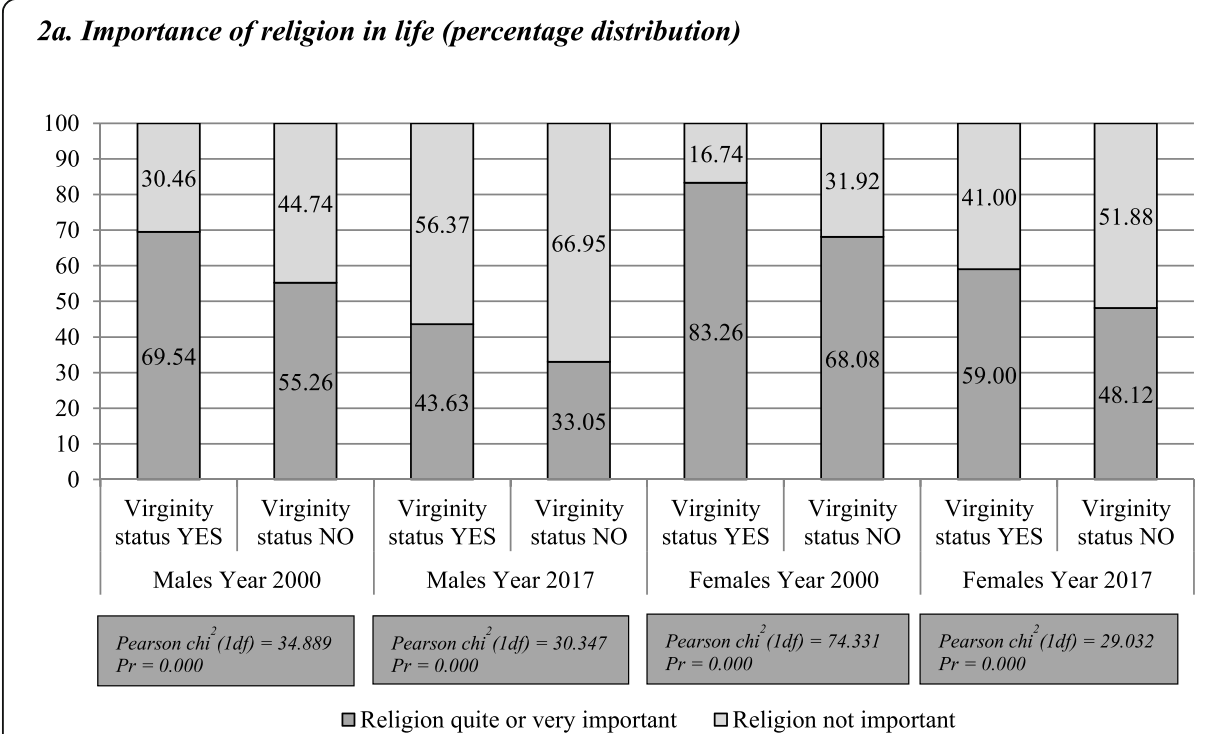

2b. Participation in religious groups (percentage distribution)

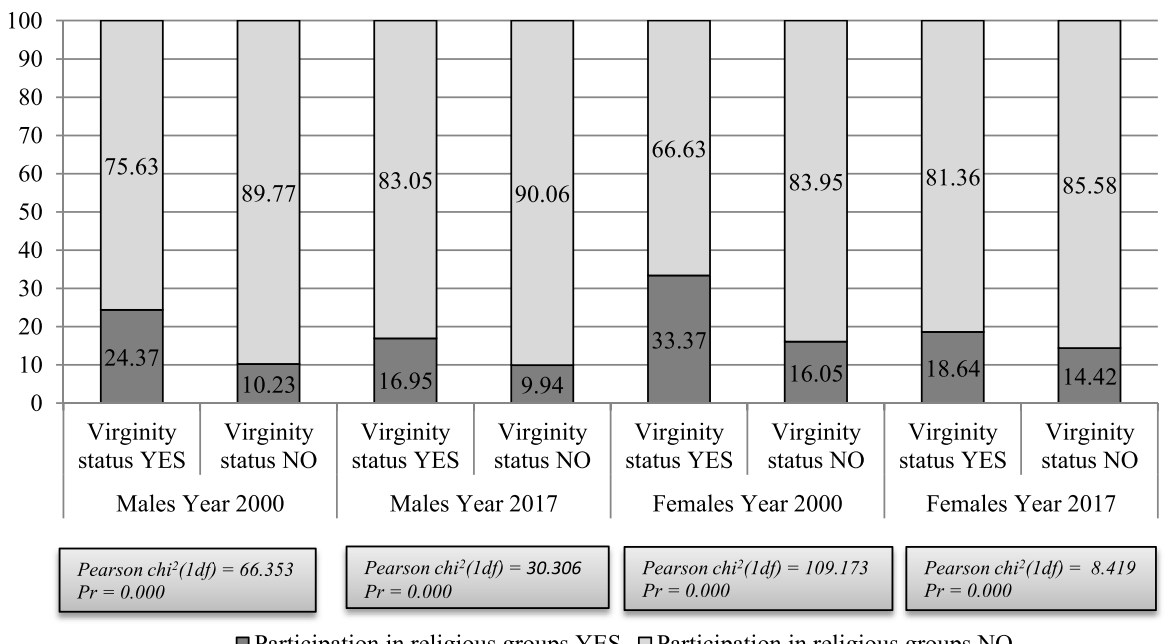

$\square$ Participation in religious groups YES $\square$ Participation in religious groups NO

Fig. 2 Religiosity: changes over time for males and females by virginity status

$p$ value $<0.001)$. These results confirm and strengthen the previous descriptive findings and clearly show that, although religion is still important in the sexual life of Italian youths, its relevance is weakening over time.

\section{Conclusions}

Research on human sexuality has spanned a wide spectrum of bio-medical, sociomedical, and socio-demographic disciplines, but there have been surprisingly few studies exploring the factors associated with the absence of sexual activity (Kim et al., 2017). To fill this gap in our understating of the sexuality of Italian young adults, the present study aimed to examine a broad set of potential correlates of virginity status among Italian university students. It is possible that each of these correlates would have been worth their own separate and more focused paper. On the other hand, this study's 
Table 3 Religiosity and virginity status over time, odds ratios

\begin{tabular}{lllll}
\hline & Males & $\begin{array}{l}\text { Females } \\
(1)\end{array}$ & $\begin{array}{l}\text { Males } \\
(2)\end{array}$ & $\begin{array}{l}\text { Females } \\
(4)\end{array}$ \\
\hline Year 2017 & $0.721^{* *}$ & $0.625^{* * *}$ & $0.691^{* * *}$ & $0.531^{* * *}$ \\
& $(0.084)$ & $(0.076)$ & $(0.062)$ & $(0.044)$ \\
Opinion about the importance of religion in life & $1.631^{* * *}$ & $1.950^{* * *}$ & $1.458^{* * *}$ & $1.514^{* * *}$ \\
& $(0.189)$ & $(0.208)$ & $(0.107)$ & $(0.106)$ \\
Interaction: Opinion about the importance of religion in life *year & 0.824 & $0.616^{* * *}$ & & \\
2017 & $(0.118)$ & $(0.083)$ & & \\
Participation in religious groups & $1.826^{* * *}$ & $1.542^{* * *}$ & $2.262^{* * *}$ & $2.192^{* * *}$ \\
& $(0.178)$ & $(0.117)$ & $(0.333)$ & $(0.222)$ \\
Interaction: Participation in religious groups ${ }^{*}$ year 2017 & & & $0.684^{*}$ & $0.446^{* * *}$ \\
Full controls & & & $(0.130)$ & $(0.067)$ \\
$N$ & & & Yes & Yes \\
Pseudo- $R^{2}$ & Yes & Yes & 5979 & 6421 \\
\hline
\end{tabular}

Notes: The table reports odds ratios of logit models' estimates based SELFY data (cumulative dataset 2000 and 2017). The dependent variable is "virginity status." Robust standard errors (corrected for heteroskedasticity) are reported in parentheses. All models control also for all the variables included in main model (see Table 1), not reported. The symbols $*^{* *},{ }^{* *}$, and * indicate that coefficients are statistically significant, respectively, at the 1,5 , and $10 \%$ level, respectively

broadness is also a merit as, in our view, it covers many different aspects associated with virginity status in Italy-a country where only outdated information is available (Barbagli et al., 2010).

Several covariates outlined a profile of Italian virgin university students in accordance with prior literature for other countries-for instance, regarding the role of family background and relationships. The balanced or intense affective relationship with the mother is positively related to virginity for both genders. These results are in line with the literature that underlines parental communication as a protective factor for maintaining virginity (Karofsky et al., 2000; Miller et al., 1998; Vazsonyi \& Jenkins, 2010) and closer child-parent affective relationship as increasing the likelihood of sexual abstinence among adolescents (Miller et al., 2001). Socialization is also pivotal for defining the profiles of virgin students. Both male and female students who have attended discos often or very often during their middle or late adolescence are remarkably less likely to be virgins. These results are coherent with previous empirical findings according to which attending socialization spaces, such as bars and clubs, relates to a higher likelihood of sexual experience for both males and females (Bozon \& Rault, 2013, 2012; Gravningen et al., 2012; Kabiru \& Orpinas, 2009).

Beside familial and interpersonal correlates, objective measures of attractiveness proved important. In line with previous findings, we found a nonlinear association between BMI and virginity. This pattern suggests that as males' BMI grows from underweight to healthy weight, the relationship with virginity is negative. Conversely, the relationship becomes positive as BMI grows to the overweight and obese range. Satisfaction with one's own body image is negatively related with virginity, although this is significant only for males. This is in line with previous findings according to which physically attractive males were more likely to become sexually active earlier in their 
lives (Weeden \& Sabini, 2007; Rhodes et al., 2005). The relationship between depression and virginity is positive and highly statistically significant for both sexes, thereby confirming those findings which outlined a relationship between sexual inactivity and poorer mental health (Dunn et al., 1999; Rosen et al., 2009; Shifren et al., 2008). It is worth recalling that literature findings about this relationship are not clear, so we highlight the existence of the relationship without making any inference about causation.

Other results add specific characteristics that make the profiles of virgin university students in Italy quite country-specific. The findings of the present study, in fact, draw attention to two crucial characteristics of Italian society: regional divisions and the role of religiosity. For male students, being born in the south, as opposed to the north, appears to be negatively related to their virginity status. Interestingly, while a more stagnating pattern was noticed for males, for females born in the south there has been a change over time in the likelihood of virgin status during tertiary education. The existence of a "resisting group" of traditionalists in southern Italy seems an interesting and worthy topic for future research.

Regarding the important role of religiosity in the Italian context, Dalla-Zuanna and Mancin (2004) concluded that the postponed sexual debuts of Italian youths, when compared to youths in other Western countries, could be explained-at least in part-by the distinctive emotional closeness of family ties, as well as by the relevant role played by the Catholic Church. Two decades later, our results show that-although religion still has a strong association with the sexuality of Italian youths - the strength of this association is weakening. Moreover, these results show that active participation in religious groups is more influent than opinions on the importance of religion in life. Modernization and secularization have generally led to deep changes in sexual and affective behaviors within post-industrial societies. Along these lines, the present study point to a loss of religion's influence in shaping the sexual behaviors of young Italians. This is not only the result of secularization, but also of a redefinition of being religious among young adults in a contemporary Italy (Garelli, 2011; Bonarini, 2013; Vignoli \& Salvini, 2014). Consequently, if devout believers become a small minority, it is possible that they could become even more adherent to religious principles, and thus, the association between virginity and religiosity could strengthen in the future.

To conclude, it is worth bearing in mind that the present study is, by its very nature, descriptive. The goal of this paper was to describe the socio-demographic profiles of virgin Italian university students, not to provide inferences about causation. Additionally, our sample is not, of course, representative of young Italians as a whole. The sexuality of our sample seems to be delayed less intense than that of their less-educated peers (for details, see Dalla-Zuanna et al., 2019). Moreover, their sexuality is in line with-or only slightly delayed and less intense than-that of university students in other academic fields (ibid). Nonetheless, our findings extend the existing research on sexuality among Italian young adults and underscore the important variability that exists in the sexual experiences of Italian students, as highlighted by the salience of several demographic-, family-, interpersonal-, bodily-, and health-related factors associated with their virginity. Our study, although mainly descriptive, can help shed light on factors related to the virginity of Italian youths and, we hope, will feed future research on the topic. 


\section{Appendix}

Table 4 Descriptive statistics of the complete sample (2000 and 2017). Males $(n=5979)$

\begin{tabular}{|c|c|c|c|c|}
\hline Variable & Mean & Std. Dev. & Min & Max \\
\hline Virginity status & 0.226 & & 0 & 1 \\
\hline Age & 21.126 & 1.479 & 18 & 26 \\
\hline First born & 0.500 & & 0 & 1 \\
\hline Father's education (number of years) & 12.267 & 3.512 & 5 & 17 \\
\hline Mother's education (number of years) & 12.349 & 3.453 & 5 & 17 \\
\hline Parents separated or divorced & 0.116 & & 0 & 1 \\
\hline Balanced or intense relationship with the father & 0.763 & & 0 & 1 \\
\hline Balanced or intense relationship with the mother & 0.903 & & 0 & 1 \\
\hline Have talked in depth with parents about sex & 0.274 & & 0 & 1 \\
\hline Having attended the disco often or very often between 16 and 18 years & 0.390 & & 0 & 1 \\
\hline Off-site student & 0.018 & & 0 & 1 \\
\hline Satisfaction about own body image nowadays & 0.821 & & 0 & 1 \\
\hline BMl & 22.766 & 2.784 & 11.318 & 42.163 \\
\hline$B M I^{2}$ & 526.034 & 134.419 & 128.105 & 1777.709 \\
\hline Having had at least one physical problem between the 14 and 18 years & 0.305 & & 0 & 1 \\
\hline Depression & 0.328 & & 0 & 1 \\
\hline Opinion about the importance of religion in life & 0.431 & & 0 & 1 \\
\hline Participation in religious groups & 0.123 & & 0 & 1 \\
\hline Area of residence: North Italy & 0.372 & & 0 & 1 \\
\hline Area of residence: Centre Italy & 0.265 & & 0 & 1 \\
\hline Area of residence: South Italy & 0.363 & & 0 & 1 \\
\hline Year 2017 & 0.674 & & 0 & 1 \\
\hline
\end{tabular}


Table 5 Descriptive statistics of the complete sample (2000 and 2017). Females $(n=6421)$

\begin{tabular}{|c|c|c|c|c|}
\hline Variable & Mean & Std. Dev. & Min & Max \\
\hline Virginity status & 0.273 & & 0 & 1 \\
\hline Age & 21.040 & 1.473 & 18 & 26 \\
\hline First born & 0.471 & & 0 & 1 \\
\hline Father's education (number of years) & 11.332 & 3.648 & 5 & 17 \\
\hline Mother's education (number of years) & 11.342 & 3.612 & 5 & 17 \\
\hline Parents separated or divorced & 0.098 & & 0 & 1 \\
\hline Balanced or intense relationship with the father & 0.698 & & 0 & 1 \\
\hline Balanced or intense relationship with the mother & 0.866 & & 0 & 1 \\
\hline Have talked in depth with parents about sex & 0.343 & & 0 & 1 \\
\hline Having attended the disco often or very often between 16 and 18 years & 0.343 & & 0 & 1 \\
\hline Off-site student & 0.023 & & 0 & 1 \\
\hline Satisfaction about own body image nowadays & 0.683 & & 0 & 1 \\
\hline BMl & 21.026 & 2.999 & 13.932 & 42.163 \\
\hline $\mathrm{BMI}^{2}$ & 451.077 & 139.831 & 194.094 & 1777.709 \\
\hline Having had at least one physical problem between the 14 and 18 years & 0.282 & & 0 & 1 \\
\hline Depression & 0.350 & & 0 & 1 \\
\hline Opinion about the importance of religion in life & 0.603 & & 0 & 1 \\
\hline Participation in religious groups & 0.183 & & 0 & 1 \\
\hline Area of residence: North Italy & 0.341 & & 0 & 1 \\
\hline Area of residence: Centre Italy & 0.258 & & 0 & 1 \\
\hline Area of residence: South Italy & 0.401 & & 0 & 1 \\
\hline Year 2017 & 0.573 & & 0 & 1 \\
\hline
\end{tabular}

\section{Abbreviations}

BMI: Body mass index; OR: Odds ratio; SELFY: "Sexual and Emotional Life of Youths" survey

\section{Acknowledgements}

We thank the anonymous reviewers for helping us improving the paper

\section{Authors' contributions}

Both authors conceived the idea of the paper. However, the different parts of the work can be attributed to each author as follows: MS performed the statistical analysis and wrote the sections about methods and results. DV wrote the introduction, the description of data, and the conclusion. Both authors contributed equally to the background section. Both authors were involved in critically reviewing the intellectual content of the manuscript. Both authors read and approved the final version of the manuscript.

\section{Funding}

The project is funded by the Italian Ministry of University and Research, 2017 MiUR-PRIN Grant "The Great Demographic Recession" Prot. No. 2017W5B55Y (PI: Daniele Vignoli).

\section{Availability of data and materials}

Data for this paper were obtained from the SELFY survey.

\section{Competing interests}

The authors declare that they have no competing interests.

\section{Author details}

${ }^{1}$ Department of Economics, Statistics and Finance "Giovanni Anania", University of Calabria, Arcavacata di Rende (CS), Italy. 'Department of Statistics, Informatics, Applications "G. Parenti", University of Florence, Florence, Italy. 
Received: 12 December 2019 Accepted: 4 June 2020

Published online: 16 June 2020

\section{References}

Angeli, A., Pillati, M., \& Rettaroli, R. (1999). Opinioni e intenzioni di vita di coppia riproduzione. In P. De Sandre, A. Pinnelli, \& A. Santini (Eds.), Nuzialità e fecondità in trasformazione: Percorsi e fattori del cambiamento (pp. 365-378). Bologna: II Mulino.

Argys, L. M., Rees, D. I., Averett, S. L., \& Witoonchart, B. (2006). Birth order and sexual behavior. Economic Inquiry, 44(2), 215233.

Barbagli, M. (2000). Sotto lo stesso tetto. Mutamenti della famiglia in Italia dal XV al XX secolo. Bologna: II Mulino.

Barbagli, M., Castiglioni, M., \& Dalla-Zuanna, G. (2003). Fare famiglia in Italia. Un secolo di cambiamenti. Bologna: II Mulino.

Barbagli, M., Dalla-Zuanna, G., \& Garelli, F. (2010). La sessualità degli italiani. Bologna: Il Mulino.

Barbagli, M., \& Saraceno, C. (Eds.). (1997). Lo stato delle famiglie in Italia. Bologna: II Mulino.

Bernardi, L., \& Mencarini, L. (2004). Italian young people facing AIDS risk: Knowledge, risk perception and sexual behaviour. In G. Dalla-Zuanna \& C. Crisafulli (Eds.), Sexual behaviour of Italian students. An international comparison (pp. 126-134). Messina: Department of Statistics, University of Messina.

Bersamin, M. M., Walker, S., Fisher, D. A., \& Grube, J. W. (2006). Correlates of oral sex and vaginal intercourse in early and middle adolescence. Journal of Research on Adolescence, 16(1), 59-68.

Billari, F. C., \& Borgoni, R. (2002). Spatial profile in the analysis of event histories: An application to first sexual intercourse in Italy. International Journal of Population Geography, 8, 261-275.

Billari, F. C., Caltabiano, M., \& Dalla-Zuanna, G. (2007). The heirs of the sexual revolution. In F. C. Billari, M. Caltabiano, \& G. Dalla-Zuanna (Eds.), Sexual and affective behaviour of students. An international comparison (pp. 1-46). Cleup: Padova.

Billari, F. C., \& Ongaro, F. (2004). First stages in partnership history and in sexual experiences. In G. Dalla-Zuanna \& C. Crisafulli (Eds.), Sexual behaviour of Italian students. An international comparison (pp. 107-124). Messina: Department of Statistics, University of Messina.

Blanchflower, D. G., \& Oswald, A. J. (2004). Money, sex and happiness: An empirical study. Scandinavian Journal of Economics, $106,393-415$

Bonarini, F. (2013). I comportamenti religiosi in Italia: Una nuova lettura Dei dati ufficiali. Religioni e Società - Rivista di scienze sociali della religione, XXVIII(77): 33-54

Bozon, M., \& Rault, W. (2012). From sexual debut to first union. Where do young people in France meet their first partners? Population, 67(3), 377-410

Bozon, M., \& Rault, W. (2013). Where do people meet their first sexual partner and their first life partner? Population Societies, number 496 January 2013.

Brewster, K. L., Cooksey, E. C., Guilkey, D. K., \& Rindfuss, R. R. (1998). The changing impact of religion on the sexual and contraceptive behavior of adolescent women in the United States. Journal of Marriage and the Family, 60, 493-504.

Brewster, K. L., \& Tillman, K. H. (2008). Who's doing it?: Patterns and predictors of youths' oral sexual experiences. Journal of Adolescent Health, 42(1), 73-80.

Brown, B. B. (1999). "You're going out with who?": Peer group influences on adolescent romantic relationships. In W. Furman, B. B. Brown, \& C. Feiring (Eds.), The development of romantic relationships in adolescence (pp. 291-329). New York: Cambridge University Press.

Caltabiano, M. (2006). The first romantic relationship of adolescents: A comparative analysis. Genus, 61(2), 141-160.

Caltabiano, M., Castiglioni, M., \& Dalla-Zuanna, G. (2004). Current sexual behaviour. In G. Dalla-Zuanna \& C. Crisafulli (Eds.), Sexual behaviour of Italian Students. An international comparison (pp. 135-157). Messina: Department of Statistics, University of Messina.

Caltabiano, M., Dalla-Zuanna, G., \& Rosina, A. (2006). Interdependence between sexual debut and church attendance in Italy. Demographic Research, 14(19), 453-484.

Carpenter, L. M. (2001). The first time/Das erstes mal: Approaches to virginity loss in U.S. and German teen magazines. Youth and Society, 33, 31-61.

Carpenter, L. M. (2002). Gender and the meaning and experience of virginity loss in the contemporary United States. Gender and Society, 16, 345-365.

Carpenter, L. M. (2005). Virginity lost: An intimate portrait of first sexual experiences. New York University; New York.

Carpenter, L. M. (2010). Gendered sexuality over the life course: A conceptual framework. Sociological Perspectives, 53(2), $155-177$.

Castiglioni, M. (1999). Analisi differenziale della nuzialità. In P. De Sandre, A. Pinnelli, \& A. Santini (Eds.), Nuzialità e fecondità in trasformazione: Percorsi e fattori del cambiamento (pp. 347-363). II Mulino: Bologna.

Castiglioni, M. (2004). First sexual intercourse and contraceptive use in Italy. In G. Dalla-Zuanna \& C. Crisafulli (Eds.), Sexual behaviour of Italian Students. An international comparison. Messina: Department of Statistics, University of Messina.

Collins, A. (2000). Surrender value of capital assets: The economics of strategic virginity loss. Journal of Bioeconomics, 2(3), 193-201.

Crawford, M., \& Popp, D. (2003). Sexual double standards: A review and methodological critique of two decades of research. The Journal of Sex Research, 40(1), 13-26.

Dalla-Zuanna, G., Caltabiano, M. C., Minello, A., \& Vignoli, D. (2019). Catching up! The sexual opinions and behaviour of Italian students (2000-2017). DiSIA working paper 2019/02.

Dalla-Zuanna, G., \& Crisafulli, C. (2004). Sexual behaviour of Italian Students. An international comparison (Eds.) Messina: Department of Statistics, University of Messina.

Dalla-Zuanna, G., De Rose, A., \& Racioppi, F. (2005). Low fertility and limited diffusion of modern contraception in Italy during the second half of the twentieth century. Journal of Population Research, 22(1), 21-48. https://doi.org/10.1007/ BF03031802.

Dalla-Zuanna, G., \& Mancin, M. (2004). Determinants of age at first sexual intercourse. In G. Dalla-Zuanna \& C. Crisafulli (Eds.), Sexual behaviour of Italian Students. An international comparison (pp. 126-134). Messina: Department of Statistics, University of Messina.

De Rose, A., Racioppi, F., \& Zanatta, A. L. (2008). Italy: Delayed adaptation of social institutions to changes in family behaviour. Demographic Research, S7(19), 665-704. 
De Rose, A. \& Vignoli, D. (2011). Families all'italiana: 150 years of history. Rivista Italiana di Demografia, Economia e Statistica, $\operatorname{LXV}(2): 121-144$.

De Sandre, P., Ongaro, F., Rettaroli, R., \& Salvini, S. (1997). Matrimonio e figli: Tra rinvio e rinuncia. Bologna: Il Mulino.

De Santis, G., Maltagliati, M., \& Salvini, S. (2015). A measure of the cultural distance between countries. Social Indicators Research, 126, 1065-1087.

Di Mauro, D. (2008). Reluctant virginity: The relationship between sexual status and self-esteem. Theses and Dissertations, 717.

Dixon, R. D. (1980). The absence of birth order correlations among unwed and married black first-conceptors. The Journal of Sex Research, 16(3), 238-244.

Dunn, K. M., Croft, P. R., \& Hackett, G. I. (1999). Association of sexual problems with social, psychological, and physical problems in men and women: A cross sectional population survey. Journal of Epidemiology and Community Health., 53, 144-148.

Esping-Andersen, G. (1990). The three worlds of welfare capitalism. Cambridge: Polity Press.

Gabrielli, G., \& Borgoni, R. (2007). Age at first sexual intercourse in Italy: A geographical approach. Genus, 63(1/2), 149-183.

Garelli, F. (2011). Religione allitaliana. L'anima del paese messa a nudo. Bologna: II Mulino.

Garelli, F., Guizzardi, G., \& Pace, E. (Eds.). (2003). Un singolare pluralismo. Bologna: II Mulino.

Giordano, P. C., Longmore, M. A., \& Manning, W. D. (2006). Gender and the meanings of adolescent romantic relationships: A focus on boys. American Sociological Review, 71(2), 260-287.

Glei, D. (1999). Measuring contraceptive use patterns among teenage and adult women. Family Planning Perspectives, 31, 7380

Gravningen, K., Furberg, A.-S., Simonsen, G. S., \& Wilsgaard, T. (2012). Early sexual behaviour and chlamydia trachomatis infection - A population based cross-sectional study on gender differences among adolescents in Norway. BMC Infectious Diseases, 12, 319 http://www.biomedcentral.com/1471-2334/12/319.

Guetto, R., Vignoli, D., \& Lachi, A. (2020). Higher parental socioeconomic status accelerates sexual debut in Italy. DiSIA working paper 2020/04

Guggino, J. M., \& Ponzetti, J. J. (1997). Gender differences in affective reactions to first coitus. Journal of Adolescence, 20, 189200.

Halpern, C. T., Waller, M. W., Spriggs, A., \& Hallfors, D. D. (2006). Adolescent predictors of emerging adult sexual patterns. Journal of Adolescent Health, 39(6), 926-e1-926e10.

Higgins, J. A., Trussell, J., Moore, N. B., \& Davidson, J. K. (2010). Virginity lost, satisfaction gained? Physiological and psychological sexual satisfaction at heterosexual debut. Journal of Sex Research, 47(4), 384-394.

Hines, D. A. (2007). Predictors of sexual coercion against women and men: A multilevel, multinational study of university students. Archives of Sexual Behavior, 36(3), 403-422.

Holland, J., Ramazanoglu, C., Sharpe, S., \& Thomson, R. (2000). Deconstructing virginity - young people's accounts of first sex. Sexual and Relationship Therapy, 15(3), 221-232.

Humphreys, T. (2013). Cognitive frameworks of virginity and first intercourse. Journal of Sex Research, 50(7), 664-675.

Iannaccone, L. R. (1998). Introduction to the economics of religion (pp. 1465-1496). XXXVI: Journal of Economic Literature.

Jaccard, J., Blanton, H., \& Dodge, T. (2005). Peer influences on risk behavior: An analysis of the effects of a close friend. Developmental Psychology, 41(1), 135-147.

James-Hawkins, L. (2019). Adolescent sexual norms and college sexual experiences: Do high school norms influence college behavior? Advances in Life Course Research, 39, 61-76

Kabiru, C. W., \& Orpinas, P. (2009). Factors associated with sexual activity among high-school students in Nairobi, Kenya. Journal of Adolescence, 32, 1023e-1039e.

Karofsky, P., Zeng, L., \& Kosorok, M. R. (2000). Relationship between adolescent-parental communication and initiation of first intercourse by adolescents. Journal of Adolescent Health, 28, 41-45.

Keller, D. (1959). Personality aspects related to misinformation about sex among college students. Science Education, 43, 156-163.

Kim, J., Tam, W., \& Muennig, P. (2017). Sociodemographic correlates of sexlessness among American adults and associations with self-reported happiness levels: Evidence from the U.S. general social survey. Archives of Sexual Behavior, 46(8), 24032415.

La Mendola, S., \& Tinto, A. (2004). On 'damned' beahaviour: Sex, drugs \& rock'n roll. In G. Dalla-Zuanna \& C. Crisafulli (Eds.), Sexual behaviour of Italian Students. An international comparison. Messina: Department of Statistics, University of Messina.

Lammers, C., Ireland, M., Resnick, M., \& Blum, R. (2000). Influences on adolescents' decision to postpone onset of sexual intercourse: A survival analysis of virginity among youths aged 13 to 18 years. Journal of Adolescent Health, 26(1), 42-48.

Landor, A. M., \& Simons, L. G. (2019). Correlates and predictors of virginity among heterosexual African American young adults. Sexuality and Culture, 23(3), 943-961.

Magin, P., Heading, G., Adams, J., \& Pond, D. (2010). Sex and the skin: A qualitative study of patients with acne, psoriasis and atopic eczema. Psychology, Health \& Medicine, 15(4), 454-462.

Manning, W. D., Giordano, P. C., \& Longmore, M. A. (2006). Hooking up: The relationship contexts of "nonrelationship" sex. Journal of Adolescent Research, 21(5), 459-483.

Manning, W. D., Giordano, P. C., \& Longmore, M. A. (2008). Adolescent dating relationships: Implications for understanding adult intimate unions. Working paper series, 8, Bowling Green State University.

Meier, A. M. (2003). Adolescents' transition to first intercourse, religiosity, and attitudes about sex. Social Forces, 81, 1031-1052.

Michalski, R., \& Shackelford, T. K. (2002). Birth order and sexual strategy. Personality and Individual Differences, 33, 661-667.

Miller, B., Benson, B., \& Galbraith, K. (2001). Family relationships and adolescent pregnancy risk: A research synthesis. Developmental Review, 21(1), 1-38.

Miller, K. S., Kotchick, B. A., Dorse, S., \& Forehand, R. (1998). Family communication about sex: What are parents saying and are their adolescents listening? Family Planning Perspective, 30, 218-222

Mohtasham, G., Shamsaddin, N., Bazargan, M., Anosheravan, K., Elaheh, M., \& Fazlolah, G. (2009). Correlates of the intention to remain sexually inactive among male adolescents in an Islamic country: Case of the republic of Iran. Journal of School Health, 79, 123-129.

Mood, C. (2010). Logistic regression: Why we cannot do what we think we can do, and what we can do about it. European Sociological Review, 26(1), 67-82. 
Moore, K. A., Miller, B. C., Glei, D., \& Morrison, D. (1995). Adolescent sex, contraception and childbearing: A review of recent research. Washington, DC: Child Trends.

Need, A., \& Evans, G. (2001). Analyzing patterns of religious participation in postcommunist Eastern Europe. British Journal of Sociology, 52(2), 229-248.

Ongaro, F. (2004). Parental family, parenting strategies and age at first sexual intercourse. In G. Dalla-Zuanna \& C. Crisafulli (Eds.), Sexual behaviour of Italian Students. An international comparison. Messina: Department of Statistics, University of Messina.

O'Sullivan, L. F., Cheng, M. M., Harris, K. M., \& Brooks-Gunn, J. (2007). I wanna hold your hand: The progression of social, romantic and sexual events in adolescent relationships. Perspectives on Sexual and Reproductive Health, 39, 100-107.

Panatto, D., Amicizia, D., Trucchi, C., et al. (2012). Sexual behaviour and risk factors for the acquisition of human papillomavirus infections in young people in Italy: Suggestions for future vaccination policies. BMC Public Health, 12, 623 (2012).

Parker, M., Heading, G., Adams, J., \& Pond, D. (2010). Sex and the skin: A qualitative study of patients with acne, psoriasis and atopic eczema. Psychology, Health \& Medicine, 15(4), 454-462. https://doi.org/10.1080/13548506.2010.484463.

Paul, C., Fitzjohn, J., Eberhart-Phillips, J., Herbison, P., \& Dickson, N. (2000). Sexual abstinence at age 21 in New Zealand: The importance of religion. Social Science \& Medicine, 51(1), 1-10.

Peplau, L. A. (2003). Human sexuality: How do men and women differ? Current Directions in Psychological Science., 12(2), 3740.

Petersen, J. L., \& Shibley, H. J. (2010). A meta-analytic review of research on gender differences in sexuality, 1993-2007. Psychological Bullettin, 136(1), 21-38.

Petersen, J. L., \& Shibley, H. J. (2011). Gender differences in sexual attitudes and behaviors: A review of meta-analytic results and large datasets. The Journal of Sex Research, 48(2-3), 149-165.

Pitts, M., \& Rahman, Q. (2001). Which behaviors constitute "having sex" among university students in the UK? Archives of Sexual Behavior, 30(2), 169-176.

Popova, O. (2017). Does religiosity explain economic outcomes? IZA world of labor 2017: 335 doi: https://doi.org/10.15185/ izawol.335, wol.iza.org

Poscia, A., La Milia, D. I., Lohmeyer, F., et al. (2015). Sexual behaviours and preconception health in Italian university students. Annuali Istituto Superiore di Sanità, 51(2), 116-120.

Regnerus, M. D. (2007). Forbidden fruit: Sex and religion in the lives of American teenagers. New York: Oxford University Press.

Revol, O., Milliez, N., \& Gerard, D. (2015). Psychological impact of acne on 21st-century adolescents: Decoding for better care. British Journal of Dermatology, 172(Suppl. 1), 52-58.

Rew, L., \& Wong, Y. J. (2006). A systematic review of associations among religiosity/spirituality and adolescent health attitudes and behaviors. Journal of Adolescent Health, 38, 433-442.

Rhodes, G., Simmons, L. W., \& Peters, M. (2005). Attractiveness and sexual behavior: Does attractiveness enhance mating success? Evolution and Human Behavior, 26(2), 186-201.

Rizzi, E. (2004). Religiousness and sexual ethics. In G. Dalla-Zuanna \& C. Crisafulli (Eds.), Sexual behaviour of Italian Students. An international comparison (pp. 249-264). Messina: Department of Statistics, University of Messina.

Rodgers, J., Rowe, D., \& Harris, D. (1992). Sibling differences in adolescent sexual behavior: Inferring process modeling composition patterns. Journal of Marriage and Family, 54(1), 142-152.

Rosen, R. C., Shifren, J. L., Monz, B. U., Odom, D. M., Russo, P. A., \& Johannes, C. B. (2009). Correlates of sexually related personal distress in women with low sexual desire. Journal of Sexual Medicine, 6, 1549-1560.

Rosina, A. (2004). First sexual approaches. In G. Dalla-Zuanna \& C. Crisafulli (Eds.), Sexual behaviour of Italian Students. An international comparison (pp. 105-106). Messina: Department of Statistics, University of Messina.

Rosina, A., \& Rivellini, G. (2004). Living arrangements, trasgressive behaviour and sexuality, Dalla-Zuanna \& C. Crisafulli (Eds.), Sexual behaviour of Italian Students. An international comparison. Messina: Department of Statistics, University of Messina.

Rostosky, S. S., Regnerus, M. D., \& Comer Wright, M. L. (2003). Coital debut: The role of religiosity and sex attitudes in the add health survey. Journal of Sex Research, 40, 358-367.

Rostosky, S. S., Regnerus, M. D., \& Wright, M. C. (2003). Coital debut: The role of religiosity and sex attitudes in the add health survey. Journal of Sex Research, 40(4), 358-367.

Salvini, S., \& Vignoli, D. (2014). Convivere o sposarsi? Bologna: II Mulino.

Sansonetti, S. (2009). Social indicators of secularisation in Italy. In B. A. Kosmin \& A. Keysar (Eds.), Secularism, women \& the state: The Mediterranean world in the 21st century (pp. 137-154). Hartford: Institute for the Study of Secularism in Society and Culture.

Schechterman, A. L., \& Hutchinson, R. L. (1991). Causal attributions, self-monitoring, and gender differences among four virginity status groups. Adolescence, 26, 659-678.

Schnarch, D., \& Maddock, J. (2003). Resurrecting sex: Solving sexual problems and revoloutionizing your relationship. New York: Harper Collins Inc..

Schreiner-Engel, P., \& Schiavi, R. C. (1986). Lifetime psychopathology in individuals with low sexual desire. The Journal of Nervous and Mental Disease, 174, 646-651.

Sheeran, P., Abrams, D., Abraham, C., \& Spears, R. (1993). Religiosity and adolescents premarital sexual attitudes and behavior: An empirical study of conceptual issues. European Journal of Social Psychology, 23(1), 39-52.

Shifren, J. L., Monz, B. U., Russo, P. A., Segreti, A., \& Johannes, C. B. (2008). Sexual problems and distress in United States women: Prevalence and correlates. Obstetrics and Gynecology, 112, 970-978.

Sprecher, S., \& Regan, P. C. (1996). College virgins: How men and women perceive their sexual status. Journal of Sex Research, $33(1), 3-15$.

Stinson, R. (2010). Hooking up in young adulthood: A review of factors influencing the sexual behavior of college students. Journal of College Student Psychotherapy, 24(2), 98-115.

Štulhofer, A., Šoh, D., Jelaska, N., Baćak, V., \& Landripet, I. (2010). Religiosity and sexual risk behavior among Croatian college students, 1998-2008. Journal of Sex Research, 48, 360-371.

Tanturri, M. L., \& Mencarini, L. (2008). Childless or childfree? An insight into voluntary childlessness in Italy. Population Development Review, 34(1), 51-77. 
Trapnell, P., Meston, C., \& Gorzalka, B. (1994). Gender differences in predictors of virginity status - social dominance, self-rated attractiveness, and religiosity. Canadian Psychology-Psychologie Canadienne, 35(2A), 149.

Vazsonyi, A., \& Jenkins, D. (2010). Religiosity, self-control, and virginity status in college students from the "Bible Belt": A research note. Journal for the Scientific Study of Religion, 49(3), 561-568.

Vignoli, D., \& Salvini, S. (2014). Religion and union formation in Italy: Catholic precepts, social pressure, and tradition. Demographic Research, 31(35), 1079-1106.

Weeden, J., \& Sabini, J. (2005). Physical attractiveness and health in Western societies: A review. Psychological Bulletin, 131, 635-653.

Weeden, J., \& Sabini, J. (2007). Subjective and objective measures of attractiveness and their relation to sexual behavior and sexual attitudes in university students. Archives of Sexual Behavior, 36(1), 79-88. https://doi.org/10.1007/s10508-006-9075-x.

Weiner-Davis, M. (2003). The sex-starved marriage. New York: Simon \& Schuster.

\section{Publisher's Note}

Springer Nature remains neutral with regard to jurisdictional claims in published maps and institutional affiliations.

Submit your manuscript to a SpringerOpen ${ }^{\odot}$ journal and benefit from:

- Convenient online submission

- Rigorous peer review

- Open access: articles freely available online

- High visibility within the field

- Retaining the copyright to your article

Submit your next manuscript at $\boldsymbol{\nabla}$ springeropen.com 